\title{
An Analysis of the Impact of Online Banking on Customer Satisfaction in Commercial Banks Based on the TRA Model (A Case Study of Stanbic Bank Lusaka Main Branch)
}

\author{
Jones Kampinda Sambaombe1, Jackson Phiri \\ ${ }^{1}$ Graduate School of Business, University of Zambia, Lusaka, Zambia \\ ${ }^{2}$ Department of Computer Sciences, School of Natural Sciences, University of Zambia, Lusaka, Zambia \\ Email: jsambaombe@gmail.com, Jackson.phiri@cs.unza.zm
}

How to cite this paper: Sambaombe, J. K., \& Phiri, J. (2022). An Analysis of the Impact of Online Banking on Customer Satisfaction in Commercial Banks Based on the TRA Model (A Case Study of Stanbic Bank Lusaka Main Branch). Open Journal of Business and Management, 10, 369-386. https://doi.org/10.4236/ojbm.2022.101022

Received: October 26, 2021

Accepted: January 17, 2022

Published: January 20, 2022

Copyright $\odot 2022$ by author(s) and Scientific Research Publishing Inc. This work is licensed under the Creative Commons Attribution International License (CC BY 4.0).

http://creativecommons.org/licenses/by/4.0/

\begin{abstract}
The convenience, easy access, and acceptable means of transacting in the customers day-to-day business operations is making more banks' customers satisfied with their service delivery. However, about $65 \%$ of Stanbic bank's customers do not use the bank's internet banking services and are dissatisfied with the bank's customer service delivery. This study analyzed the impact of online banking on customer satisfaction in commercial banks based on the TRA model using Stanbic Bank as a case study. This study employed the cross-sectional study design conducted at Stanbic Bank's headquarters in Lusaka district targeting bank customers. The sample size for the study was 196. Stratified Sampling was employed, respondents were selected by circular systematic random sampling, and a questionnaire was used to collect data. Kendall's tau-b correlation was used to determine the relationship between online banking and customer satisfaction of banking services. Binary logistic regression was used to determine the influence of online banking on the outcome variable (customer satisfaction). A weak positive correlation between the use of online banking and customer satisfaction was established $[(\tau \mathrm{b}=.169, p$ $=.012)]$. Interacting gender of "being male", having secondary education or below, negative behavioral belief, negative attitude, negative behavioral intention, and none usage of online banking reduces customer satisfaction $[(p$ $=.046) ;(\mathrm{CI}: 95 \%)],[(p=.039) ;(\mathrm{CI}: 95 \%)],[(p=.019) ;(\mathrm{CI}: 95 \%)],[(p$ $=.018) ;($ CI: $95 \%)],[(p=.036) ;(C I: 95 \%)]$ respectively. Therefore, in the quest increase to increase customer satisfaction, the bank needs to consider
\end{abstract}


these parameters in their strategic planning if it is to maintain or grow its customer base.

\section{Keywords}

Customer Satisfaction, Internet Banking, Theory of Reasoned Action (TRA)

\section{Introduction}

The Internet is changing the banking and financial industry as far as the idea of core products/services is concerned and the way these are bundled, proposed, conveyed and expended (Phillips et al., 2017). It is a priceless and an incredible asset in driving development, supporting growth, promoting innovation and enhancing competitiveness (Phillips et al., 2017). Banks and different organizations are going to Information Technology (IT) to improve business proficiency, service quality and draw in new clients (Li et al., 2021). Technological advancements have been recognized to add to the dispersion channels of banks and these electronic conveyance channels are aggregately alluded to as electronic banking (Teshome, 2019). The development of banking innovation has been driven by changes in distribution channels as through the Automated teller machine (ATM), Phone-banking, Tele-banking, PC-banking and most recently Internet banking (Hussain et al., 2017). Across the globe, the banking industry has evolved over the past decades in the areas of technology and one of such areas is online banking. Online banking helps businesses and individuals to access banking services from the luxury offices and homes on their personal computer. Internet banking innovations have made it easy for the bank to attract many corporate and retail customers. In Zambia, until the year 2010, Internet banking was not common. After 2010 when most banks were made all-inclusive banks, internet banking turned out to be normal and effectively assessable to all who subscribe to the service (Hussain et al., 2017). There are minimal inquiries about internet banking on the Zambian financial sector as contrasted with other electronic financial developments (Nguyen, 2019). It is for this reason that this study endeavored to carry out an analysis of the impact of online banking on Zambian Commercial Banks with reference to Stanbic Zambia. The banking industry has evolved over the past decades in the areas of technology and one of such areas is online banking (Arakpogun et al., 2017). This has made it easy for the bank to attract many corporate and retail customers convenience, easy access and acceptable means of transacting in their day-to-day business operations.

Despite numerous advantages that online banking offers, most customers still opt for physical interaction when it comes to customer service delivery (Shanthi \& Desti, 2015). This has been the challenge that STANBIC bank faces from its 
customers. In 2020 the bank invested huge sums of money to transform its banking operations by making online banking user friendly as a tool to aid excellent customer service delivery and yet only $35 \%$ of the customers are utilizing the online services fully (Stanbic Zambia Limited Annual Report, 2020). This was an indication that about $65 \%$ of their customers were dissatisfied with their customer service. Therefore, this study was conducted to investigate the impact of online banking on customer satisfaction in Zambia using Stanbic bank as a case study. The aim of this study was to investigate the impact of online banking on customer satisfaction in commercial banks based on the TRA model using Stanbic Bank as a case study.

\section{Key Literature Review (Table 1)}

Table 1. Literature review summary.

\begin{tabular}{ll}
\hline N0: $\quad$ Author & \multicolumn{1}{c}{ Study Title } \\
\hline & $\begin{array}{l}\text { Factors affecting adoption and use of } \\
\text { mobile banking services in Zambia based } \\
\text { on TAM Models }\end{array}$ \\
\hline 1. Sakala \& Phiri (2019)
\end{tabular}

The study suggested that there is a positive relationship between use of e-banking services and perceived ease of use, usefulness, attitudes, external factors, intention, system use

Performance expectancy is the key to adoption of E-banking services in Zambia
2. Daka \& Phiri (2019) E-banking Services Based on the UTAUT Model
Factors Driving the Adoption of Model

Model

3. Lishomwa \& Phiri (2020)
There is a very strong relationship between internet banking and performance expectation, control factor and social influence

A model for improving e-tax adoption in

4. Soneka \& Phiri (2019) the rural of Zambia based on the TAM Models
E-tax payment and submission systems is convenient and less costly for those in the rural areas but there is however, greater need to enhance sensitization

The modified TAM model indicated its usefulness e-banking adoption
5. Mwiya et al. (2017) Adoption: Evidence from Bank Customers in Zambia
Financial inclusion is an important aspect of economic development in developing countries. ICT infrastructure is key to spearhead such development

6. Kawimbe (2020)

An assessment of the impact of mobile financial services on Financial inclusion and economic development in Zambia

None of the studies analyzed the Impact of online banking on customer satisfaction in commercial banks based on the

\subsection{Conceptual Framework (Modified TRA Model) Adapted}

The adapted Theory of Reasoned Action (TRA) (Figure 1) is a model that finds its origins in the field of social psychology. This model was developed by Fishbein and Ajzen (1975). Al-Suqri and Al-Kharusi (2015) define the links between 
Independent Variables

Dependent Variable

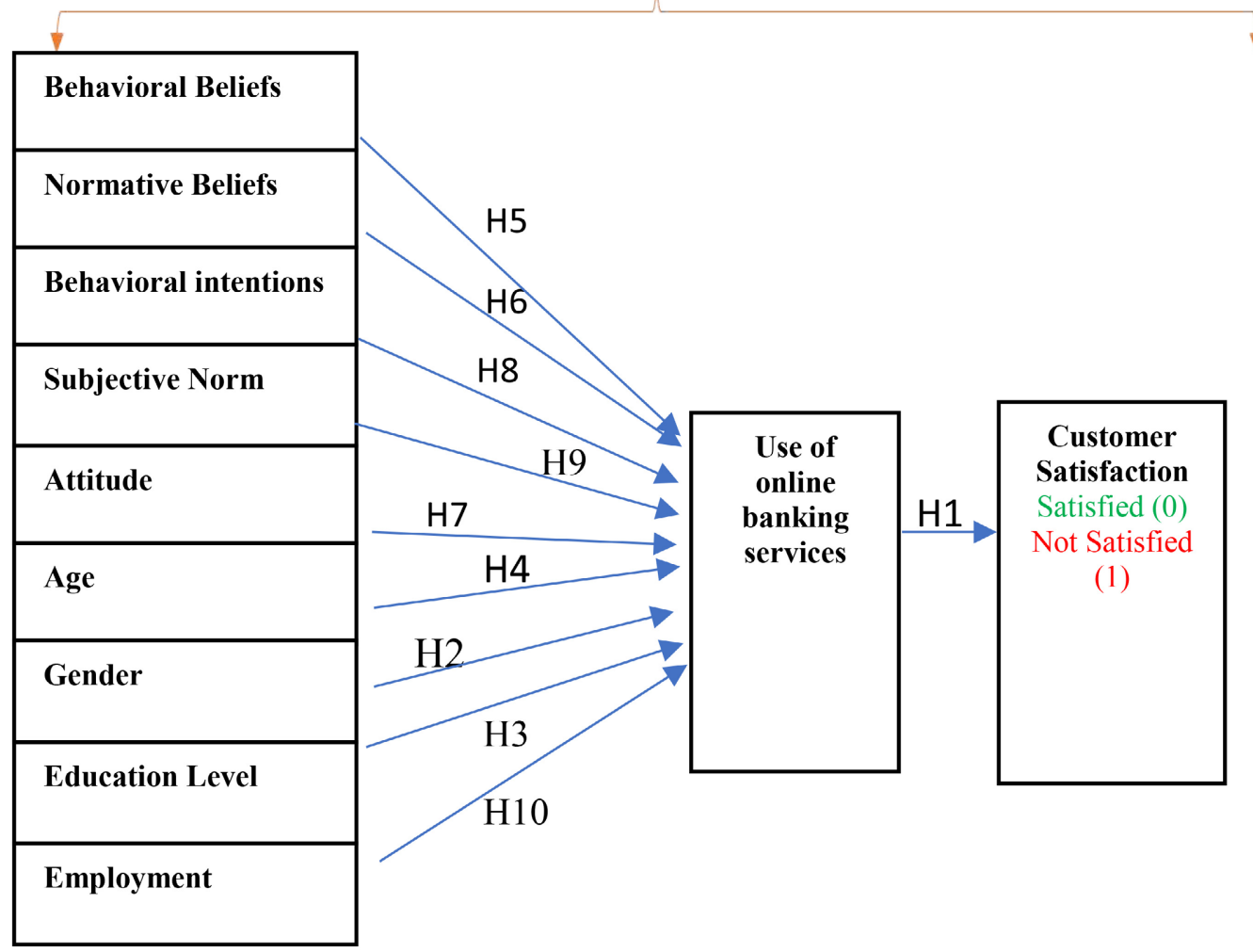

Figure 1. The framework and development of hypothesis.

beliefs, attitudes, norms, intentions, and behaviors of individuals. According to this model, a person's behavior is determined by its behavioral intention to perform it. This intention is itself determined by the person's attitudes and his subjective norms towards the behavior. Fishbein and Ajzen (1975) define the subjective norms as "the person's perception that most people who are important to him think he should or should not perform the behavior in question" (Fishbein \& Ajzen, 1975).

\subsection{Hypotheses}

The following section looks at the conceptual frame work that was used to formulate the hypothesis. The descriptions outlined establish the background for the independent variables.

$\mathrm{H} 1$ : The use of online banking influences customer service satisfaction

$\mathrm{H} 2$ : The interaction between being Male and the none use of online banking influences customer service satisfaction.

H3: The interaction between having secondary education or below and the none use of online banking influences customer service satisfaction.

H4: The interaction between being aged 36+ years and the none use of online banking influences customer service satisfaction. 
H5: The interaction between negative behavioral beliefs and the none use of online banking influences customer service satisfaction.

H6: The interaction between negative normative beliefs and the none use of online banking influences customer service satisfaction.

H7: The interaction between customers negative attitude and the none use of online banking influences customer service satisfaction.

H8: The interaction between negative behavioral intention and the none use of online banking influences customer service satisfaction.

H9: The interaction between customers negative perception and the none use of online banking influences customer service satisfaction.

H10: The interaction between being unemployed and the none use of online banking influences customer service satisfaction

\section{Research Methodology}

This study employed a cross-sectional study design. The study was carried at Stanbic Bank main branch in Lusaka. The study targeted customers with personal and/or business accounts. The sample size was estimated based on the Comparative Study of Ghana and Spain .85 [(85.0\%; Amoah-Mensah (2011)], at the confidence interval of $95 \%$ (Z-score 1.96) and a precision/margin of error of $5 \%$, the sample size was estimated at 196 with a $2.5 \%$ (5) over sampling included non-response, never available and other situations which may have affected the initial sample size; the sample size of 201 ensured a $95 \%$ confidence interval estimate where the proportion of Stanbic bank customers were satisfied within 5\% of the true proportion. The sample size was determined as indicated below:

The sample size estimation was done as bellow:

$$
\begin{aligned}
& n=\left(\frac{Z \alpha}{d}\right)^{2}=\left(\frac{1.96}{0.05}\right)^{2}=196 \\
n= & N * n /(n+N-1) \\
= & 28211 * 196 /(196+28211-1) \\
= & (\text { Finite population adjustment })
\end{aligned}
$$

where:

$n=$ is the sample size.

$Z a=1.96$ at $95 \%$ Confidence interval which is the value from the standard normal distribution reflecting the confidence level as required (e.g., $Z=1.96$ for 95\%).

$P=$ Proportion of bank customers are not satisfied (.85 or $85 \%)$ based on the Comparative Study of Ghana and Spain (Amoah-Mensah, 2011).

$d=5 \%$ margin of error/precision ( $d$ is the desired margin of error).

$N=28,211$ (Stanbic Zambia Limited Annual Report, 2020).

The sample size for the study was estimated at 196 . However, with a $2.5 \%$ non-response rate the total sample size was 201 . 
However, the response rate was at $77.6 \%$. Therefore, all analyses were based on only 156 respondents (77.6\%). Stratified sampling and circular systematic sampling methods were employed in the study. Both primary and secondary data were collected. Primary data was collected using a questionnaire (Simpson, 2006), and secondary was gathered from published works. To ensure validity and reliability of the data which was collected and the results of the study, the questionnaire was pre-test at two different branches; Zambia National Commercial Bank with five (5 participants) and Standard Charted Bank with (5 participants). This was done to check for consistence as well as to check whether the questionnaire was able to measure what it intended (Taherdoost, 2016). Data was analysed at univariate, bivariate and multivariate levels. Kendall's tau-b correlation was used to determine the relationship between online banking and customer satisfaction of banking services. To determine the influence of online banking on the outcome variable (customer satisfaction), multivariate analysis, was done by the use of Binary logistic regression (Jindal et al., 2017).

\section{Binary Logistic the Model}

Binary logistic regression was used to estimate the (Log Odds) of a customer being unsatisfied. Binary logistic regression equation was estimated as follows:

$$
\operatorname{Logit}(P)=b_{0}+b_{1} X_{1}+b_{2} X_{2}+b_{3} X_{3}+\cdots+b_{p} X_{p}+E
$$

$P$. denotes the probability of the customer being satisfied $=1$, and unsatisfied $=0$.

$b_{1} \ldots b_{p}$ : denotes the coefficients of the independent variables.

$X_{1} \ldots X_{p}$ : denotes the independent variables. All dichotomous variables were converted into dummies before they could be entered in the model. The model was built using the Enter Method in which all the predictors were entered at once. However, only predictors which were significantly associated with customer satisfaction were advanced to multivariate analysis.

\section{Results and Discussion}

\subsection{Results}

\subsubsection{Univariate Analysis (Background Characteristics)}

Of the total 156 respondents $64 \%$ were males while $36 \%$ were females (Figure 2). In terms of age groups (Figure 3) 62.2\% were in age group 18 - 35 years while $37.8 \%$ were aged $36+$ years. Figure 4 shows that $71.8 \%$ had tertiary education while $36 \%$ had "secondary or below" education. Figure 5 shows that $65.4 \%$ were employed while $34.6 \%$ were unemployed. Figure 6 shows the distribution of respondents by customer satisfaction. The figure indicates that $59 \%$ were satisfied with the bank's service provision while $41 \%$ indicated that they were not satisfied with the bank's services. Figure 7 shows the distribution of respondents by use of on-line banking. That $35.9 \%$ were using internet banking while $64.1 \%$ indicated that they were not using internet banking.

\section{Gender}




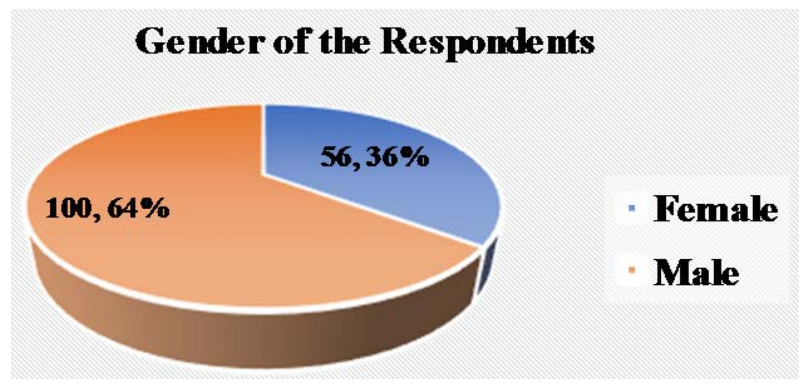

Figure 2. Gender of respondents.

\section{Age Group}

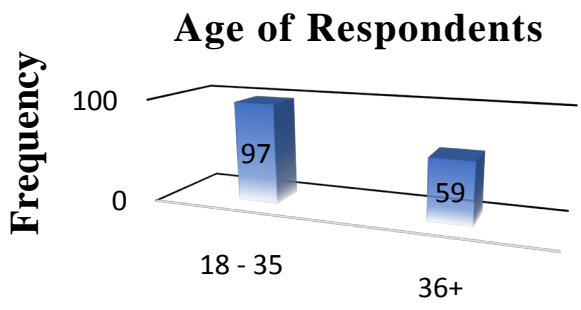

Age-group

Figure 3. Age-group of respondents.

Education Level

Education Level of Respondents

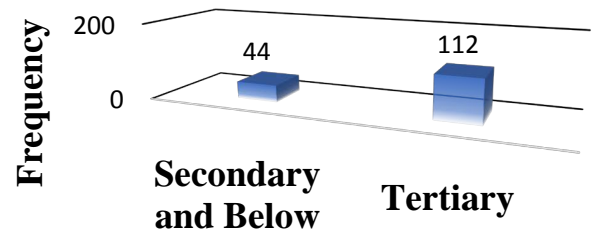

Education Level

Figure 4. Education level of the respondents.

\section{Employment Status}

\section{Employment Status of Respondents}

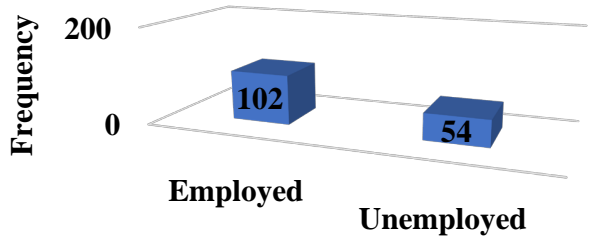

\section{Employment Status}

Figure 5. Employment status of respondents. 


\section{Customer Satisfaction}

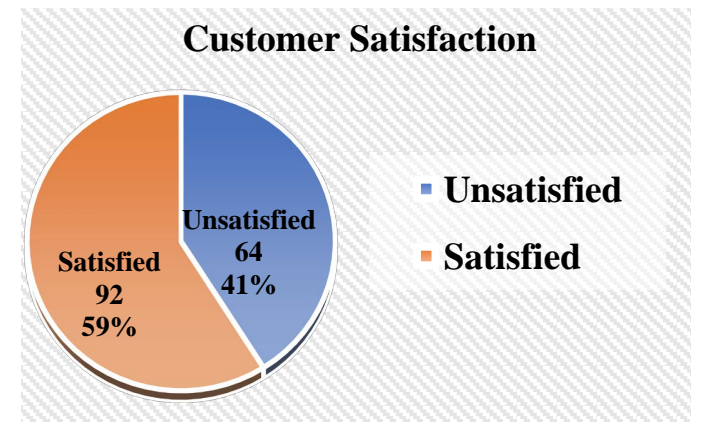

Figure 6. Customer satisfaction.

\section{Use of Online Banking}

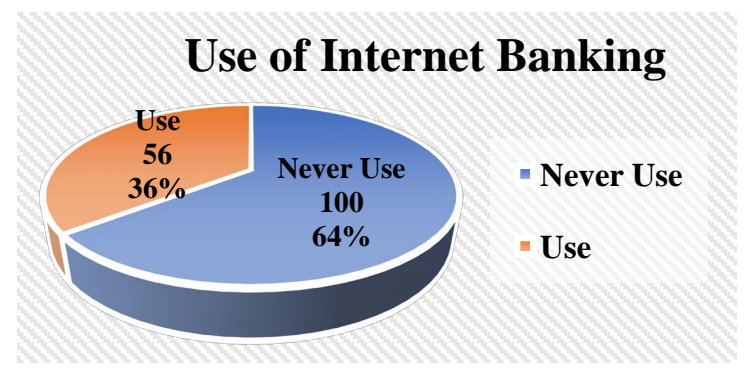

Figure 7. Use of internet banking.

\subsubsection{Bivariate Analysis}

This was the second level analysis which was done to establish the direction of the relationship between online banking and customer service satisfaction. Kendall's tau_b was used to establish the relationship between the use of online banking and customer satisfaction. To allow for Kendall's tau_b to be employed to analyze the relationship between using online banking and customer satisfaction, the two variables were ranked (ordinal scaled). This was done to address specific objective one or to test hypothesis 1 . See Table 2.

1) H1: The use of online banking influences customer service satisfaction positively

A Kendall's tau-b correlation was run to determine the relationship between the use of online banking and customer satisfaction amongst 156 participants. There was a weak, positive correlation between the use of online banking and customer satisfaction, which was statistically significant ( $\tau \mathrm{b}=.169, p=.012$ ). Therefore, the research hypothesis was accepted (Table 4).

\subsubsection{Multivariate Analysis}

\section{Binary Logistic Regression Model Building \\ Model Two (2)}

Table 3 shows the output of the second model of binary logistic regression. In this advanced model, holding all the independent variables constant, customer 
Table 2. Kendall's Tau_b correlation between use of online banking and customer satisfaction.

\begin{tabular}{|c|c|c|c|c|}
\hline & & & $\begin{array}{l}\text { Customer } \\
\text { Satisfaction }\end{array}$ & $\begin{array}{c}\text { Online Banking } \\
\text { Use }\end{array}$ \\
\hline \multirow{6}{*}{$\begin{array}{c}\text { Kendall's } \\
\text { tau_b }\end{array}$} & \multirow{3}{*}{$\begin{array}{l}\text { Customer } \\
\text { Satisfaction }\end{array}$} & Correlation Coefficient & 1.000 & $.169^{*}$ \\
\hline & & Sig. (2-tailed) & . & .012 \\
\hline & & $\mathrm{N}$ & 156 & 156 \\
\hline & \multirow{3}{*}{$\begin{array}{c}\text { Online Banking } \\
\text { Use }\end{array}$} & Correlation Coefficient & $.169^{*}$ & 1.000 \\
\hline & & Sig. (2-tailed) & .012 & $\cdot$ \\
\hline & & $\mathrm{N}$ & 156 & 156 \\
\hline
\end{tabular}

${ }^{\star}$ Correlation is significant at the .05 level (2-tailed).

Table 3. Binary logistic regression model two.

\begin{tabular}{|c|c|c|c|c|c|c|c|c|}
\hline & \multirow{2}{*}{$\mathrm{B}$} & \multirow{2}{*}{ S.E. } & \multirow{2}{*}{ Wald } & \multirow{2}{*}{ df } & \multirow{2}{*}{ Sig. } & \multirow{2}{*}{$\operatorname{Exp}(B)$} & \multicolumn{2}{|c|}{$95 \%$ C.I. for $\operatorname{EXP}(B)$} \\
\hline & & & & & & & Lower & Upper \\
\hline Never Use (1) & -.710 & .353 & 4.04 & 1 & .044 & 2.034 & 1.019 & 4.064 \\
\hline Male (1) by Never use (1) & -.964 & .483 & 3.98 & 1 & .046 & .381 & .148 & .982 \\
\hline Secondary and Below (1) by Never Use (1) & 1.163 & .563 & 4.26 & 1 & .039 & 3.198 & 1.061 & 9.641 \\
\hline Never Use (1) by Unemployed (1) & .294 & .460 & .409 & 1 & .523 & 1.342 & .545 & 3.305 \\
\hline Negative Behaviour Belief (1) by Never Use (1) & -1.129 & .480 & 5.52 & 1 & .019 & .323 & .126 & .829 \\
\hline Negative Normative Belief (1) by Never use (1) & -.011 & .481 & .001 & 1 & .981 & .989 & .385 & 2.539 \\
\hline Negative Attitude (1) by Never use (1) & -1.051 & .442 & 5.63 & 1 & .018 & 2.859 & 1.201 & 6.807 \\
\hline Negative Subjective Norms (1) by Never Use (1) & .574 & .437 & 1.72 & 1 & .189 & 1.775 & .754 & 4.178 \\
\hline Negative Behaviour Intentions (1) by Never Use (1) & -.916 & .438 & 4.37 & 1 & .036 & 2.500 & 1.060 & 5.898 \\
\hline Age Group 36+ (1) by Never Use (1) & -.386 & .499 & .598 & 1 & .439 & .680 & .256 & 1.808 \\
\hline Constant & .878 & .279 & 9.92 & 1 & .002 & .415 & & \\
\hline
\end{tabular}

a. Variable(s) entered on step 1: Male ${ }^{\star}$ Never Use, Secondary and Below ${ }^{\star}$ Never Use, Never Use ${ }^{*}$ Unemployed, Negative Behaviour Belief ${ }^{\star}$ Never Use, Negative Normative Belief ${ }^{\star}$ Never Use, Negative Attitude ${ }^{\star}$ Never Use, Negative Subjective Norms ${ }^{\star}$ Never Use, Negative Behaviour Intentions ${ }^{\star}$ Never Use Age Group ${ }^{\star}$ Never Use.

satisfaction increases by $.878 \log$ odds $[(P=.002) ;(\mathrm{CI}: 95 \%)]$ and singularly, the none usage of online banking reduces customer satisfaction by $.710 \log$ odds $[(p$ $=.044) ;(\mathrm{CI}: 95 \%)]$. Furthermore, this model was fitted in order to test hypotheses 2 to 10 of the study.

2) H1: The interaction between being Male and the none use of online banking influences customer service satisfaction negatively: Interacting gender of "being male" and none usage of online banking reduces customer satisfaction by $.964 \log$ odds: [( $p=.046)$; (CI: 95\%)]: the research hypothesis was accepted (Table 4). This means that being male and none use of online banking increases customer dissatisfaction. 
Table 4. Tested hypotheses.

\begin{tabular}{lcc}
\hline \multicolumn{1}{c}{ Hypothesis } & Result & Decision \\
$\begin{array}{l}\text { Tested Hypotheses }(1-10) . \\
\begin{array}{l}\text { 1) } H 1 \text { : The use of online banking influences customer service } \\
\text { satisfaction. }\end{array}\end{array} \quad(\tau \mathrm{b}=.169, p=.012)$. & (H1: Accepted). \\
$\begin{array}{l}\text { 2) H1: The interaction between being Male and the none use of online } \\
\text { banking influences customer service satisfaction negatively. }\end{array}$ & $\begin{array}{c}\text { This relationship is significant at } \\
{[(p=.046) ;(\mathrm{CI}: 95 \%)] .}\end{array}$ & (H1: Accepted)
\end{tabular}

3) H1: The interaction between having secondary education or below and the none use of online banking influences customer service satisfaction negatively.

This relationship is significant at $[(p=.039) ;(\mathrm{CI}: 95 \%)]$.

4) H1: The interaction between being unemployed and the none use of online banking influences customer service satisfaction negatively.

This relationship is not significant $\quad$ (H0: Accepted).

5) H1: The interaction between negative behavioral beliefs and the none use of online banking influences customer service satisfaction negatively.

This relationship is significant at $[(p=.019) ;(\mathrm{CI}: 95 \%)]$.

(H1: Accepted)

6) H1: The interaction between negative normative beliefs and the use of online banking influences customer service satisfaction negatively.

This relationship is not significant $\quad$ (H0: Accepted).

7) H1: The interaction between negative attitude and the use of online banking influence customer service satisfaction negatively.

This relationship is significant at $[(p=.018) ;(\mathrm{CI}: 95 \%)]$.

(H1: Accepted)

8) Hl: The interaction between negative customers perception (negative subjective norms) and the use of online banking influences customer service satisfaction positively.

9) H1: The interaction between negative behavioral intention and the use of online banking influences customer service satisfaction negatively.

This relationship is not significant

(H0: Accepted).

10) H1: The interaction between being aged $36+$ years and the none use of online banking influences customer service satisfaction negatively.

This relationship is significant at $[(p=.036) ;(\mathrm{CI}: 95 \%)]$.

This relationship is not significant
(H1: Accepted)

(H0: Accepted).

3) H1: The interaction between having secondary education or below and the none use of online banking influences customer service satisfaction negatively: Interacting negative behavioral belief and none usage of online banking increases customer satisfaction by 1.163 log odds: [( $p=.039)$; (CI: 95\%)]: the research hypothesis is rejected (Table 4), because the relationship is positive and reduces customer dissatisfaction.

4) H1: The interaction between being unemployed and the none use of online banking influences customer service satisfaction negatively: Interaction of being unemployed with none usage of online banking, and customer satisfaction was not significant. Therefore, this hypothesis was rejected (Table 4).

5) H1: The interaction between negative behavioral beliefs and the none use of online banking influences customer service satisfaction negatively. Interaction of negative behavioral belief with none usage of online banking, and customer satisfaction is negative: [ $(p=.019)$; (CI: 95\%)]: the research hypothesis is accepted (Table 4). This further implies that, interacting negative behavioral belief and none usage of online banking reduces customer satisfaction by 1.13 log odds. This means that having negative behavioral beliefs and none use of on- 
line banking increases customer dissatisfaction.

6) H1: The interaction between negative normative beliefs and the use of online banking influences customer service satisfaction negatively: The relationship between, the interaction of negative normative beliefs with none usage of online banking, and customer satisfaction was not significant. Therefore, this hypothesis was rejected (Table 4).

7) H1: The interaction between negative attitude and the use of online banking influences customer service satisfaction negatively: Interaction of negative attitude with none usage of online banking, and customer satisfaction is negative: [ $(p=.018)$; (CI: 95\%)]: the research hypothesis was accepted (Table 4). This means that, interacting negative attitude and none usage of online banking reduces customer satisfaction by 1.051 log odds. This interaction increases customer dissatisfaction.

8) H1: The interaction between negative customers perception (negative subjective norms) and the use of online banking influences customer service satisfaction positively.

The relationship between, the interaction of negative customer perception with none usage of online banking, and customer satisfaction was not significant. Therefore, this hypothesis was rejected (Table 4).

9) H1: The interaction between negative behavioral intention and the use of online banking influences customer service satisfaction negatively. Interaction of negative behavioral intention with none usage of online banking, and customer satisfaction is negative: [ $(p=.036)$; (CI: 95\%)]: the research hypothesis was accepted (Table 4). This implies that, interacting negative behavioral intentions and none usage of online banking reduces customer satisfaction by .916 log odds. This interaction increases customer dissatisfaction

10) H1: The interaction between being aged $36+$ years and the none use of online banking influences customer service satisfaction negatively.

The relationship between, the interaction of being aged 36+ years with no usage of online banking, and customer satisfaction was not significant. Therefore, this hypothesis was rejected (Table 4).

\subsubsection{Model Goodness of Fit}

The second study model illustrated $96.5 \%$ accuracy of data prediction. The model further showed that variations of $8.4 \%$ (Cox \& Snell $\mathrm{R}^{2}: .084$ ), in customer satisfaction were explained by the model. The -2 Log Likelihood value of 1083.017e, with Hosmer and Lemeshow test values of .170 $(P>.05)$ ], showed that the model estimates were acceptable and gave indication of a good model fit of the model on the data.

\section{Discussion}

The general objective of this study was to analyze the impact of online banking on customer satisfaction in commercial banks based on the TRA model using 
Stanbic Bank as a case study. It was established that the use of online banking influence customer service satisfaction positively. This analysis was done using the Kendall's tau-b correlation and there was a weak, positive correlation between the use of online banking and customer satisfaction, which was statistically significant. The more customers use internet banking services the more satisfied they become with the banking services These results are consistent with the results of the study which was done by (Hammoud et al., 2018). The possible explanation to this could be that E-Banking improves reliability, efficiency, and ease of service delivery with high responsiveness and communication; and ensures good security and privacy which impact positively on customer satisfaction (Li et al., 2021; Poon, 2008; Sardana \& Bajpai, 2020). Literature further, indicates that the banking industry has been rapidly developing and that the use of internet banking is believed to be an efficient and viable tool to create customer value (Li et al., 2021).

Binary logistic regression was fitted on the data to determine the effect and influence of the independent variables on the dependent variable. Interactions were done between the use of internet banking and other characteristics of customers to determine the interaction effect on their bank service satisfaction. This was done to address the second specific objective of the study to test the aligned hypotheses.

It was established that the interaction between being Male and the none use of online banking influences customer service satisfaction negatively. This shows that, interacting gender of "being male" and none usage of online banking reduces customer satisfaction on bank services. Males were found to use internet banking less than females. The use of internet banking was higher among females compared to males. These results are in contradiction with the result of a study done in Nigeria which found that gender differences moderated the acceptance of e-banking of users in the research context (Ayo et al., 2012). Computer self-efficacy and perceived ease of use were of a serious concern to females, but less so for their male counterparts. In their study, the use of internet banking was higher among males (Ayo et al., 2012). This difference could be explained by the fact that, with women empowerment which is grass rooted from school level, more women, of late, are finding it much easier to work with technology as they are getting more exposed to it compared to males. This is putting women in the position to catch up with technology and employing it more to simplify their lives. The less usage of internet banking by males makes them less satisfied with the bank services (Ayo et al., 2014). In another study, which was done by Jiménez and Díaz (2019) there was no effect of gender on bank technology use contradicting the studies which found that the adoption of technology, such as internet banking, was relatively lower in women compared to men and the current study which found that the use of internet banking is lower among men.

The interaction between having secondary education or below and the none use of online banking influence customer service satisfaction negatively. Having 
secondary education or below with none usage of online banking, and customer satisfaction is negative. This means that having secondary education or less interaction with the none use of internet banking makes customers less satisfied with the services provided by the bank. People with less or no education may be finding it very difficult to interact with internet machinery, computers; among others. This makes them to less appreciate the internet banking services and consequently fail to appreciate the internet banking and other innovations which the bank sets up to improve service delivery to the customers. These results are consistent with the results of a study which was done by (Jiménez \& Díaz, 2019) which found that, education impacts preference for using technology to transfer funds and review bank statements among others activities. Furthermore, the association between higher education and increased technology use has been documented in many past studies and is tied closely to higher socioeconomic status, greater need for innovative learning, and higher level of access to resources (Jiménez \& Díaz, 2019).

It was determined in this study that the interaction between negative behavioral beliefs and the none use of online banking influences customer service satisfaction negatively. Customers with negative behavioral belief may not appreciate bank innovations and when interacting with the none use of internet banking get less satisfied. This further implies that, interacting negative behavioral belief and none usage of online banking reduces customer satisfaction. The possible explanation to this scenario could be that one's negative subjective probability that a positive action result may or may not be achieved determines what effort would be required to carry out an action. Mixed feelings and approaches are employed in the use of internet banking at different levels. Where there are negative behavioral characteristics, the execution of activities may guarantee no positive result. These results are consistent with the findings of the study which was done by Liao et al. (1999).

The interaction between negative attitude and the use of online banking influences customer service satisfaction negatively. As indicated in table 5 the relationship between, the interaction of negative attitude with none usage of online banking, and customer satisfaction is negative. This means that, people with negative attitude towards the use of internet banking were less satisfied compared to the ones with the positive attitude. This interaction negatively affects customer satisfaction. Literature clearly indicates that the banking industry is continuously enhancing and augmenting services on the internet, for many banking services among others; bill payment, electronic balance inquiries, tracking of expenditures and credit cards, monitoring transaction histories, transferring money between bank accounts and mobile-bank accounts, investment tracking, analyzing securities. The results of the current study are consistent with many study results including those of a study done in Pennsylvania by Kaynak and Harcar (2005), which examined consumer attitudes towards online banking. Their empirical study findings showed that online bank marketing 
would gain importance and its use would accelerate at a faster rate in the coming years as many people respondents indicated positive attitudes towards the innovations and the subsequent resultant improved banking services.

Negative behavioral intention and the none use of online banking was found to influence customer service satisfaction negatively. The relationship between, the interaction of negative behavioral intention with none usage of online banking, and customer satisfaction is negative indicating that customer with negative behavior intentions, that is, having a negative thought of employing internet banking innovations reduced the satisfaction levels of the customer. The negative thought of using internet banking and having a preconceived thought and feeling about bank services came out as a clearer negative predictor of customer satisfaction. Bashir and Madhavaiah (2015) also found that attitude, perceived risk, perceived lack of enjoyment and distrust determined the customers' behavioral intentions to use Internet banking. Furthermore, other studies show that, the direct effect of perceived website design difficult of use was seen as its indirect effects on perceived usefulness, attitude and behavioral intentions on the delivery of bank services (AlHaliq \& AlMuhirat, 2016; Ayo et al., 2014; Kaynak \& Harcar, 2005; Li et al., 2021). Therefore, positive behavior intention is a significant positive predictor of customer satisfaction as it indicates the ultimate appreciation of bank innovations and consequently the resultant service delivery of the bank.

\section{Linking the TRA Model to the Study Results}

This study adapted the TRA model developed by Fishbein et al. (1980) to try and explain how the use or none use internet banking impacts on customer satisfaction on the banking services. As suggested by the theory that; because many extraneous factors influence stability of intention, the relationship between intention and behavior depends on two factors: 1) the measure of intention must correspond to the behavioral criterion in action, target, context, and time; and 2) intention does not change before the behavior is observed. The TRA specifies that behavioral intention is a function of two determinants: a personal factor termed attitude toward behavior, and a person's perception of social pressures termed subjective norm (Fishbein et al., 1980).

In this study the model clearly defines the links between beliefs, attitudes, norms, intentions, and behaviors of individuals. According to this model, a person's behavior was determined by the behavioral intention to perform banking activities online in order to achieve their intended satisfaction on bank service delivery. The extended modified interactional mechanisms have explained that negativity on beliefs, attitudes, intentions, and the none use on online banking have negative effect on the satisfaction of the banks' customers. This is to mean that, positivity on the stated parameters creates an environment where customer enjoy the banks innovations and broadened service delivery through internet banking services which are accessible at any minute of interest. The model has 
explained that internet usage increases customer satisfaction on bank services and positively affects the attitude of customers towards the services provided by the bank. Individual characteristics of customers; age gender, occupation, education level, where incorporated in the interactions of the adapted model and the resultant effects were able to indicate effect direction.

The implementation of this model was not able to incorporate all the key parameters which might be able to explain all the variations and implications of the aspects of indicated factors on the model. The binary logistic regression model was built on the parameters of the TRA through the manipulation of certain variables to allow for ease of analysis and clearer statistic interpretation. Future studies may require employing Multinomial regression in respect of the natural falling of the parameters of the TRA model so as to enhance the explanation of the natural phenomena.

\section{Conclusion}

This study was conducted on Stanbic Bank customers to determine the association between the use of internet banking and their satisfaction on the bank's service delivery and the impact of its use or none use interacted with other factors on the satisfaction of service delivery. By use of the Kendall's tau-b correlation, results showed a weak positive correlation between the use of online banking and customer satisfaction. Furthermore, the interactions which were found to be associated with customer dissatisfaction were the interactions between; gender of "being male", having secondary education or below, negative behavioral belief, negative attitude, negative behavioral intention, and none usage of online banking. This means that "being male", having more than secondary education, positive behavioral belief, positive attitude, positive behavioral intention, and using of online banking were positively associated with customer satisfaction. Therefore, in the quest increase to increase customer satisfaction, the bank needs to consider these parameters in its strategic planning if it is to maintain or grow its customer base.

\section{Limitations}

1) This study's findings cannot be generalized because it is consumer-based research and only one bank was covered as a case study.

2) The study focused only on some technological, behavioral, and attitudinal factors. It left out many customer-specific factors and other psychographic and behavioral factors including cost, perceived value, service quality determinations, which could have provided more significant insight into the innovation adoption process.

\section{Recommendations}

This study recommends that: 
1) The bank needs to establish a motivation factor for people to embrace the use of internet banking for all bank services. Customers especially those with low education, the males and the unemployed may need to be oriented properly on the usage of internet banking. Those with negative behavioral beliefs, negative attitude, negative behavioral intentions may need to be educated on the advantages of the innovations of the bank and their benefit.

2) Further studies may have to focus on some customer-specific factors and other psychographic and behavioral factors including cost, perceived value, service quality determinations, which were left out in this study which could have provided more significant insight on the innovation adoption process.

\section{Acknowledgements}

The author wishes to acknowledge all participants for their valuable contribution to the study and not forget the research supervisor for his relentless dedication.

\section{Conflicts of Interest}

The author declares no conflict of interest regarding the publication of this paper.

\section{References}

AlHaliq, H. A., \& AlMuhirat, A. A. (2016). Customer Satisfaction with Electronic Banking Services in the Saudi Banking Sector. Asian Social Science, 12, 139-146. https://doi.org/10.5539/ass.v12n5p139

Al-Suqri, M. N., \& Al-Kharusi, R. M. (2015). Ajzen and Fishbein's Theory of Reasoned Action (TRA) (1980). In Information Seeking Behavior and Technology Adoption: Theories and Trends (pp. 188-204). IGI Global. https://doi.org/10.4018/978-1-4666-8156-9.ch012

Amoah-Mensah, A. (2011). Customer Satisfaction in the Banking Industry: A Comparative Study of Ghana and Spain. Universitat de Girona.

Arakpogun, O., Wanjiru, R., \& Whalley, J. (2017). Impediments to the Implementation of Universal Service Funds in Africa-A Cross-Country Comparative Analysis. Telecommunications Policy, 41, 617-630. https://doi.org/10.1016/j.telpol.2017.05.003

Ayo, C. K., Ifinedo, P., Ekong, U. O., Adesina, A. A., Usoro, A., Majewski, G., Ifinedo, P., \& Arikpo, I. (2012). An Empirical Evaluation of the Effects of Gender Differences and Self-Efficacy on E-Banking Adoption in Nigeria: A Modified Technology Acceptance Model. In Leveraging Developing Economies with the Use of Information Technology: Trends and Tools (pp. 179-181). IGI Glob. https://doi.org/10.4018/978-1-4666-1637-0.ch010

Ayo, C., Mbarika, V., \& Oni, A. (2014). Gender Differences and Self-Efficacy in the Adoption of e-Democracy in Africa. In 14th European Conference on E-Government (p. 34).

Bashir, I., \& Madhavaiah, C. (2015). Consumer Attitude and Behavioural Intention towards Internet Banking Adoption in India. Journal of Indian Business Research, 7, 67-102. https://doi.org/10.1108/JIBR-02-2014-0013

Daka, C. G., \& Phiri, J. (2019). Factors Driving the Adoption of E-Banking Services Based 
on the UTAUT Model. International Journal of Business Management, 14, 43-52. https://doi.org/10.5539/ijbm.v14n6p43

Fishbein, M., \& Ajzen, I. (1975). A Bayesian Analysis of Attribution Processes. Psychological Bulletin, 82, 261. https://doi.org/10.1037/h0076477

Fishbein, M., Jaccard, J., Davidson, A. R., Ajzen, I., \& Loken, B. (1980). Predicting and Understanding Family Planning Behaviors. In Understanding Attitudes and Predicting Social Behavior. Prentice Hall.

Hammoud, J., Bizri, R. M., \& El Baba, I. (2018). The Impact of e-Banking Service Quality on Customer Satisfaction: Evidence from the Lebanese Banking Sector. Sage Open, 8. https://doi.org/10.1177/2158244018790633

Hussain, Z., Das, D., Bhutto, Z. A., Hammad-u-Salam, M., Talpur, F., \& Rai, G. (2017). E-Banking Challenges in Pakistan: An Empirical Study. Journal of Computing and Communication, 5, 1-6. https://doi.org/10.4236/jcc.2017.52001

Jiménez, J. R. Z., \& Díaz, I. A. (2019). Educational Level and Internet Banking. Journal of Behavioral and Experimental Finance, 22, 31-40.

https://doi.org/10.1016/j.jbef.2019.01.004

Jindal, R., Malhotra, R., \& Jain, A. (2017). Prediction of Defect Severity by Mining Software Project Reports. International Journal of System Assurance Engineering and Management, 8, 334-351. https://doi.org/10.1007/s13198-016-0438-y

Kawimbe, S. (2020). An Assessment of the Impact of Mobile Financial Services on Financial Inclusion and Economic Development in Zambia.

Kaynak, E., \& Harcar, T. D. (2005). Consumer Attitudes towards Online Banking: A New Strategic Marketing Medium for Commercial Banks. International Journal of Technology Marketing, 1, 62-78. https://doi.org/10.1504/IJTMKT.2005.008125

Li, F., Lu, H., Hou, M., Cui, K., \& Darbandi, M. (2021). Customer Satisfaction with Bank Services: The Role of Cloud Services, Security, e-Learning and Service Quality. Technology in Society, 64, Article ID: 101487. https://doi.org/10.1016/j.techsoc.2020.101487

Liao, S., Shao, Y. P., Wang, H., \& Chen, A. (1999). The Adoption of Virtual Banking: An Empirical Study. International Journal of Information Management, 19, 63-74. https://doi.org/10.1016/S0268-4012(98)00047-4

Lishomwa, L., \& Phiri, J. (2020). Adoption of Internet Banking Services by Corporate Customers for Forex Transactions Based on the TRA Model. Open Journal of Business and Management, 8, 329-345. https://doi.org/10.4236/ojbm.2020.81020

Mwiya, B., Chikumbi, F., Shikaputo, C., Kabala, E., Kaulung’ombe, B., \& Siachinji, B. (2017). Examining Factors Influencing e-Banking Adoption: Evidence from Bank Customers in Zambia. https://doi.org/10.2139/ssrn.2987982

Nguyen, K. (2019). Technology Contribution in Electronic Commerce: Customer Experience of Online Shopping.

Phillips, F., Yu, C.-Y., Hameed, T., \& El Akhdary, M. A. (2017). The Knowledge Society's Origins and Current Trajectory. International Journal of Innovation Studies, 1, 175-191. https://doi.org/10.1016/j.ijis.2017.08.001

Poon, W.-C. (2008). Users' Adoption of e-Banking Services: The Malaysian Perspective. Journal of Business \& Industrial Marketing, 23, 59-69.

Sakala, L., \& Phiri, J. (2019). Factors Affecting Adoption and Use of Mobile Banking Services in Zambia Based on TAM Model. Open Journal of Business Management, 7, 1380-1394. https://doi.org/10.4236/ojbm.2019.73095

Sardana, S., \& Bajpai, V. N. (2020). E-Banking Service Quality and Customer Satisfaction: 
An Exploratory Study on India. International Journal of Services and Operations Management, 35, 223-247. https://doi.org/10.1504/IJSOM.2020.105272

Shanthi, R., \& Desti, K. (2015). Consumers' Perception on Online Shopping. Journal of Marketing and Consumer Research, 13, 14-21.

Simpson, E. P. (2006). Examining Employee Satisfaction, Customer Service and Customer Satisfaction in a Retail Banking Organization. University of North Texas.

Soneka, P. N., \& Phiri, J. (2019). A Model for Improving E-Tax Systems Adoption in Rural Zambia Based on the TAM Model. Open Journal of Business and Management, 7, 908-918. https://doi.org/10.4236/ojbm.2019.72062

Stanbic Zambia Limited Annual Report 2020.Pdf. Stanbic Bank Zambia.

Taherdoost, H. (2016). Validity and Reliability of the Research Instrument. How to Test the Validation of a Questionnaire/Survey in a Research. https://doi.org/10.2139/ssrn.3205040

Teshome, N. (2019). Determinant Factors Influencing the Implementation of Electronic Banking in Commercial Bank of Ethiopia, Addis Ababa. PhD Thesis, St. Mary's University. 